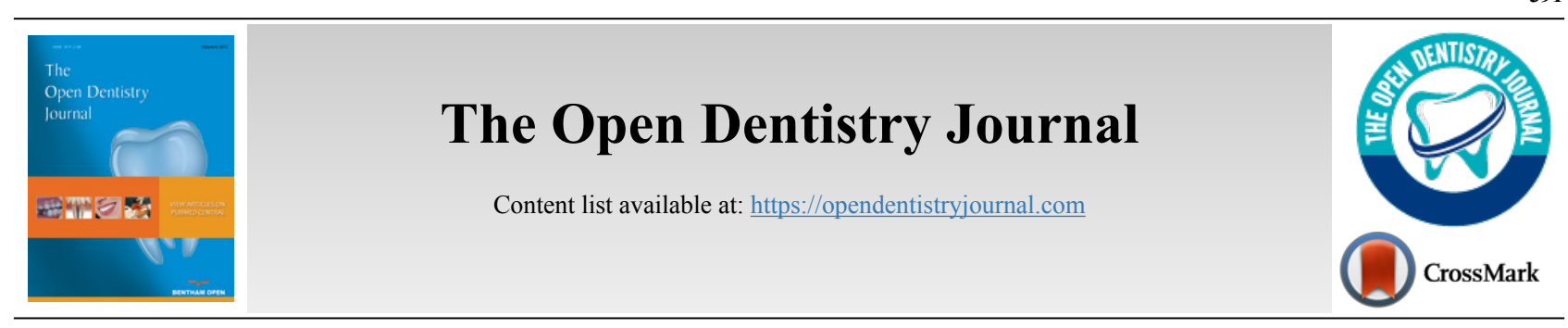

EDITORIAL

\title{
Special Issue Introduction on the Maxillofacial Rehabilitation: Biomaterials and Techniques
}

Dinesh Rokaya ${ }^{1, *}$

${ }^{1}$ Department of Clinical Dentistry, Walailak University International College of Dentistry, Walailak University, Bangkok 10400, Thailand

I am humbled and delighted to be the Guest Editor for this Special Issue of Maxillofacial Rehabilitation: Bio-materials and Techniques.

Often, maxillofacial rehabilitation includes prosthetic rehabilitation of patients with compromised oral tissues, maxillary defects, mandibular defects, and the restoration of orofacial defects. Maxillofacial rehabilitation is a challenge due to limited material properties, soft-tissue mobility, compromised retention of prostheses, and high esthetic demand. Esthetics is the primary consideration for patients looking for prosthetic treatment $[1,2]$. The fabrication of a prosthesis combines the knowledge of art and science. The size and position of teeth, coloration, and texture of the prosthesis must be indiscernible from the surrounding tissues. The facial landmarks are important to produce a pleasant facial harmony expression in esthetic restorations. The human face has a variety of shapes. Prosthetic reconstruction helps in restoring functional disability apart from esthetics.

Maxillary central incisors play an important role in dental esthetics. In this thematic issue, the importance of facial proportion and esthetics is highlighted. Golden proportion and golden standard of teeth can be studied to evaluate the face and teeth esthetics [3, 4]. Wadud and et al. studied the golden proportion and golden standard of teeth, but they found that there was no golden proportion and golden standard were found in face and anterior teeth in Thai subjects. The teeth and face proportions other than golden proportion and golden standard were found. Regarding teeth and face proportion, gender variations have been noted [5].

Various biomaterials are used in maxillofacial rehabilitation. Metal-free materials are widely used, such as

\footnotetext{
* Address correspondence to this author at the Department of Clinical Dentistry, Walailak University International College of Dentistry, Walailak University, Bangkok 10400, Thailand;

E-mails: dineshrokaya115@hotmail.com,dinesh.ro@wu.ac.th
}

zirconia-based ceramic and prostheses, which are fabricated via computer-aided design and computer-aided manufacturing (CAD/CAM) system for restorations from single to full mouth rehabilitation. Petkosit and Sanohkan evaluated the effect of pre-curing pressure on the shear bond strength of zirconia to the resin cement. They found that the pre-curing pressure did not influence the shear bond strength of the zirconia and resin cement. Herein, a review article is also added on the role of dentists in the COVID-19 pandemic in various aspects of dentistry, including general dentistry and restorative dentistry.

The review article lead by Hai Anh Trian presents various applications of finite element applications in implant dentistry. The article discusses the application of a finite element in implant dentistry to study the stress distributions on adjoining bone, the biomechanics of dental implant and bone, the implant-bone interface, and study the fatigue behaviors of the implant.

Finally, I believe the scholarly articles in this Special Issue highlight the uses of various technologies and techniques in maxillofacial rehabilitation.

\section{REFERENCES}

[1] Mack MR. Perspective of facial esthetics in dental treatment planning. J Prosthet Dent 1996; 75(2): 169-76.

[http://dx.doi.org/10.1016/S0022-3913(96)90095-5] [PMID: 8667276]

[2] Humagain M, Rokaya D, Srii R, Dixit S, Kafle D. Gender based comparison of gingival zenith esthetics. Kathmandu Univ Med J 2016; 14(54): $148-52$. [PMID: 28166072]

[3] Levin EI. Dental esthetics and the golden proportion. J Prosthet Dent 1978; 40(3): 244-52.

[http://dx.doi.org/10.1016/0022-3913(78)90028-8] [PMID: 279670]

[4] Rokaya D, Kitisubkanchana J, Wonglamsam A, Santiwong P, Srithavaj T, Humagain M. Nepalese esthetic dental (NED) proportion in nepalese population. Kathmandu Univ Med J 2015; 13(51): 244-9. [PMID: 27180372]

[5] Rokaya D, Suttagul K, Sapkota B, Maharjan SK. Gender based comparison of the relationships of maxillary anterior teeth and facial measurements. J Int Dent Med Res 2018; 11(1): 465-9.

\section{(C) 2021 Dinesh Rokaya}

This is an open access article distributed under the terms of the Creative Commons Attribution 4.0 International Public License (CC-BY 4.0), a copy of which is available at: (https://creativecommons.org/licenses/by/4.0/legalcode). This license permits unrestricted use, distribution, and reproduction in any medium, provided the original author and source are credited. 